\title{
A LÍRICA MODERNA NO BRASIL ATRAVÉS DE QUATRO POEMAS DE MARIA CARPI
}

\author{
Ana Cristina Steffen \\ Submetido em 20 de maio de 2019. \\ Aceito para publicação em 12 de agosto de 2019. \\ Cadernos do IL, Porto Alegre, n. ${ }^{\circ}$ 58, outubro. p. 163-176.
}

\section{POLÍTICA DE DIREITO AUTORAL}

Autores que publicam nesta revista concordam com os seguintes termos:

(a) Os autores mantêm os direitos autorais e concedem à revista o direito de primeira publicação, com o trabalho simultaneamente licenciado sob a Creative Commons Attribution License, permitindo o compartilhamento do trabalho com reconhecimento da autoria do trabalho e publicação inicial nesta revista.

(b) Os autores têm autorização para assumir contratos adicionais separadamente, para distribuição não exclusiva da versão do trabalho publicada nesta revista (ex.: publicar em repositório institucional ou como capítulo de livro), com reconhecimento de autoria e publicação inicial nesta revista.

(c) Os autores têm permissão e são estimulados a publicar e distribuir seu trabalho online (ex.: em repositórios institucionais ou na sua página pessoal) a qualquer ponto antes ou durante o processo editorial, já que isso pode gerar alterações produtivas, bem como aumentar o impacto e a citação do trabalho publicado.

(d) Os autores estão conscientes de que a revista não se responsabiliza pela solicitação ou pelo pagamento de direitos autorais referentes às imagens incorporadas ao artigo. A obtenção de autorização para a publicação de imagens, de autoria do próprio autor do artigo ou de terceiros, é de responsabilidade do autor. Por esta razão, para todos os artigos que contenham imagens, o autor deve ter uma autorização do uso da imagem, sem qualquer ônus financeiro para os Cadernos do IL.

\section{POLÍTICA DE ACESSO LIVRE}

Esta revista oferece acesso livre imediato ao seu conteúdo, seguindo o princípio de que disponibilizar gratuitamente o conhecimento científico ao público proporciona sua democratização.

\section{http://seer.ufrgs.br/cadernosdoil/index}

Segunda-feira, 07 de outubro de 2019. 


\title{
A LÍRICA MODERNA NO BRASIL ATRAVÉS DE QUATRO POEMAS DE MARIA CARPI
}

\section{THE MODERN LYRIC POETRY IN BRAZIL THROUGH FOUR POEMS OF MARIA CARPI}

\author{
Ana Cristina Steffen*
}

\begin{abstract}
RESUMO: Apesar do movimento simbolista no Brasil não ser uma estética que encontra consenso entre os estudiosos, é inegável que a lírica moderna, que teve sua expressão consolidada a partir do Simbolismo francês, segue influenciando a produção poética de maneira geral. Em Estrutura da lírica moderna, Hugo Friedrich faz uma análise da poesia de Baudelaire, Rimbaud e Mallarmé. Suas afirmações se mostram profícuas no estudo da influência dos três poetas. Tal influência é percebida durante toda a produção poética no Brasil ao longo do século XX e faz-se presente ainda nos dias atuais; exemplo disso é a poetisa Maria Carpi. Buscando estabeceler um diálogo entre as características da lírica moderna e a poesia de Carpi, serão analisados quatro poemas da autora.
\end{abstract}

PALAVRAS-CHAVE: Maria Carpi; Hugo Friedrich; Lírica moderna.

\begin{abstract}
Although the symbolist movement in Brazil is not an aesthetic that finds consensus among the scholars, it is undeniable that the modernist lyric poetry, which had its expression consolidated following the French Symbolism, continues influencing the poetic production in general. In Structure of modern lyric poetry, Hugo Friedrich analyzes of the poetry of Baudelaire, Rimbaud and Mallarmé. His statements prove fruitful in the study of the influence of the three poets. Such influence is perceived throughout the poetic production in Brazil during the 20th Century and it is still present nowadays; an example of this is the poet Maria Carpi. Seeking to establish a dialogue between the characteristics of the modernist lyric poetry and the poetry of Carpi, four poems of the author will be analyzed.
\end{abstract}

KEYWORDS: Maria Carpi; Hugo Friedrich; Modernist Lyric Poetry.

A origem da chamada "lírica moderna" tem como marco inicial o movimento simbolista, surgido na Europa durante o século XIX. Segundo Álvaro Cardoso Gomes, em introdução à coletânea de textos doutrinários A estética simbolista (1985), o Simbolismo teve como centro irradiador a França, mais especificamente a publicação de As flores do mal, de Charles Baudelaire, em 1857. O movimento, que tem dentre as suas características "o culto ao vago, do mistério, a busca do ideal, somados ao desejo do encontro da "poesia pura" (GOMES, 1985, p. 25), também encontrou representantes em outros poetas franceses do século XIX: Arthur Rimbaud, Stéphane Mallarmé e Paul Verlaine. Sua influência se estendeu a países como Itália, Espanha, Portugal e, tardiamente, Rússia. Na Inglaterra e Alemanha, por outro lado, manifestou-se um Romantismo sui generis, anterior - e precursor - ao Simbolismo - o que não impediu posteriormente a influência do movimento francês em obras, por exemplo, de autores

\footnotetext{
* Doutoranda em Teoria da Literatura pela Pontificia Universidade Católica do Rio Grande do Sul (PUCRS). E-mail: ana.steffen@acad.pucrs.br.
} 
ingleses, como $O$ retrato de Dorian Gray (1891), de Oscar Wilde, e de autores alemães, como As elegias de Duíno (1923), de Rainer Maria Rilke (GOMES, 1985). No Brasil, Cruz e Sousa, com Broquéis (1893), é o responsável pela introdução do Simbolismo. Porém, segundo Gomes (1985), as influências dos poetas europeus foram mais bem assimiladas pelo simbolista brasileiro Alphonsus de Guimaraens. A presença do movimento simbolista no Brasil, contudo, não encontra consenso entre críticos e estudiosos da literatura. Alfredo Bosi, por exemplo, em sua História concisa da literatura brasileira, levanta a seguinte questão:

Contemporâneos ou vindos pouco depois dos poetas parnasianos e dos narradores realistas, Cruz e Sousa, Alphonsus de Guimaraens e os simbolistas da segunda geração não tiveram atrás de si uma história social diversa da que viveram aqueles. $\mathrm{O}$ que nos propõe um problema de gênese literária: $\mathrm{o}$ movimento teria nascido aqui por motivos internos, ou foi obra de imitação direta de modelos franceses? (BOSI, 1982, p. 300).

Após recapitular brevemente o contexto da época e a trajetória de Cruz e Sousa - e de outros poetas considerados simbolistas -, Bosi conclui que

\begin{abstract}
o Simbolismo não exerceu no Brasil a função relevante que o distinguiu na literatura europeia, na qual o reconheceram por legítimo precursor o imagismo inglês, o surrealismo francês, o expressionismo alemão, o hermetismo italiano, a poesia pura espanhola. Aqui, encravado no longo período realista que o viu nascer e lhe sobreviveu, teve algo de surto epidêmico e não pode romper a crosta da literatura oficial. Caso o tivesse feito, outro e mais precoce teria sido o nosso Modernismo, cujas tendências para o "primitivo" e o "inconsciente" se orientaram numa linha bastante próxima das ramificações irracionalistas do Simbolismo europeu (BOSI, 1982, p. 301-302, grifo do autor).
\end{abstract}

Independentemente dessa questão, fato é que a lírica moderna, que tem sua melhor expressão a partir dos simbolistas franceses, seguiu influenciando os poetas brasileiros e a produção lírica de maneira geral desde o século XIX. O alemão Hugo Friedrich, em 1956, publicou Estrutura da lírica moderna, em que é apresentada uma análise da poesia de Baudelaire, Rimbaud e Mallarmé. Apesar dos mais de 60 anos de publicação, até hoje a obra permanece como uma das referências centrais para o estudo da lírica. ${ }^{1}$ No prefácio da primeira edição, afirma o autor que os fundadores da lírica moderna são Rimbaud e Mallarmé. Para Friedrich,

Entre eles e a poesia de nossa época, perduram elementos em comum que não se pode explicar como simples influxos nem se precisa explicar como tal, mesmo nos lugares em que os influxos sejam reconhecíveis. Trata-se de elementos estruturais em comum ou, melhor, de uma tessitura básica, surpreendentemente constante nos mais varidos fenômenos da lírica moderna. Essa estrutura originária de muitos filões alguns dos quais já existentes no século XVIII, fundiu-se - por volta de 1850 na teoria poética e por volta de 1870 , na prática - em um todo que é, certamente, muito complexo, mas também muito coerente. Isto ocorreu na França. As leis estilísticas dos poetas atuais tornam-se claras a partir de Rimbaud e

\footnotetext{
1 Alfonso Berardinelli, por exemplo, no livro Da poesia à prosa (2007), coletânea de ensaios seus escritos entre 1983 e 2001, afirma que o estudo mais aprofundado e abrangente de natureza teórica sobre poesia é o de Friedrich - a despeito das várias críticas que Berardinelli dirige à Estrutura.
} 
Mallarmé, e, por outro lado, o espantoso modernismo destes últimos é explicado a partir dos poetas hodiernos (FRIEDRICH, 1978, p. 9-10).

As afirmações de Friedrich, ainda que dirigidas à poesia europeia, podem ser estendidas à lirica brasileira. Afrânio Coutinho, por exemplo, em Introdução à literatura no Brasil, confirma as ideias de Friedrich quando declara que a contribuição do Simbolismo "à literatura foi imperecível, havendo quem lhe empreste a categoria de movimento mais importante, pelo seu aspecto positivo e pela herança legada, a poesia moderna" (COUTINHO, 1980, p. 215, grifo meu). No Brasil, a influência simbolista permaneceu ao longo do Modernismo, durante o qual se impôs "a busca de uma linguagem essencial, afim às experiências metafísicas e herméticas de certo veio rilkeano da lírica moderna, e que se reconhece na primeira fase de Vinicius de Moraes, em Cecília Meireles, em Henriqueta Lisboa, em Emílio Moura” (BOSI, 1982, p. 491), dentre outros. Segundo Bosi (1982, p. 492), esses poetas seriam "herdeiros maduros da experiência formal simbolista"; e, aqueles surgidos posteriormente, na década de 1950, renovaram "trinta anos depois, a maneira parnasiano-simbolista contra a qual reagira masculamente a Semana; mas renovava-se sob a égide da poesia existencial europeia de entre guerras, de filiação surrealista, o que lhe conferia um estatuto ambíguo de tradicionalismo e modernidade" (BOSI, 1982, p. 521, grifos do autor).

No entanto, a influência dos primeiros representantes da lírica moderna não se encerrou com a poesia surgida na década de 1950. Italo Moriconi, em Como e por que ler a poesia brasileira do século $X X$, traz duas considerações que exemplificam a continuidade dessa presença na segunda metade do século passado. Primeiramente, o autor aponta que o grupo paulista do Concretismo - que, no Brasil, tem maior força entre as décadas de 1950 e 1970 - considerava-se discípulo da fase mais experimental de Mallarmé, da qual o maior expoente é a obra Um lance de dados, de 1897. Segundo, a presença de Baudelaire na poesia brasileira que, apesar de antiga, é forte e permanece. Indicativa disso é, segundo o autor, a possibilidade de ler o poema $A$ carniça, do poeta francês, como o núcleo da poética do brasileiro Augusto dos Anjos (1884 - 1914). Mas também são exemplares dessa presença os pastiches - bem mais recentes - dos poemas baudelairianos, como é o caso do texto produzido por Ana Cristina Cesar, em 1984, a partir de $O$ cisne (MORICONI, 2002). Esses são alguns dos casos que possibilitam afirmar que a influência dos primeiros simbolistas europeus pode ser percebida durante todo o século XX. E, ademais, ela manifestou-se ainda no final do século XX e início do século XXI. Exemplo disso é a poesia produzida por Maria Carpi. Nascida em 1939, em Guaporé, Rio Grande do Sul, a poetisa publicou sua primeira obra, Nos gerais da dor, em 1990. Desde então, a autora já acumula mais de 10 livros e diversos prêmios, dentre eles o Revelação da Associação Paulista dos Críticos de Arte (1990), a Menção Honrosa no Casa de las Américas (1999), em Cuba, e o Açorianos na categoria poesia (1997). Para este trabalho, foram selecionados quatro dos seus poemas, sendo dois da obra Vidência e acaso (1992) e dois de A força de não ter força (2003).

Em Vidência e acaso, como o próprio título anuncia, são apresentadas, ao longo de todos os 85 poemas - sem título, identificados apenas por numeração -, a associação, a comparação ou a oposição entre as ideias de vidência e acaso. Nelly Novaes Coelho, em ensaio sobre a obra de Carpi, afirma que o núcleo temático de Vidência e acaso é "o contínuo embate entre o visível (o ‘acaso' que aparentemente dirige a vida humana) e o invisível (a 'vidência', o olhar interrogante que, nos momentos de iluminação, vê a verdade oculta pelas aparências)" (COELHO, 2002, p. 37). Segundo o Pequeno Dicionário Houaiss da Língua Portuguesa (2015), "vidência" é a qualidade 
sobrenatural de quem é vidente; "vidente", por sua vez, é aquele "que pode ver o passado, prever o futuro ou ver cenas nas quais não está presente" (HOUAISS, 2015, p. 969). Já o "acaso" é conceituado como sorte, destino, sendo um "acontecimento casual, incerto ou imprevisível" (HOUAISS, 2015, p. 11). Sendo assim, desde o título da obra, já é exposta uma relação antitética ao colocar vidência e acaso lado a lado. Diz o poema de número 57:

\author{
No acaso, eu encontro a palavra. \\ $\mathrm{Na}$ vidência, a palavra quer meu \\ corpo para proferir-me. No acaso, \\ eu declaro a árvore. Na vidência, \\ escuto-a dizer-me: Não vinga \\ jogares um grão de minha espécie \\ no coração de um sulco. Terás \\ de ser-me a terra do grão em ti \\ enterrado. Sem a visão do fruto (CARPI, 1992, p. 67).
}

Apesar da oposição entre as ideias de vidência e acaso por si só já constituir-se como significação ao longo de todo o livro, neste poema é possível também associar a referida vidência ao conceito de poeta vidente (voyant) de Rimbaud. Segundo ele, "o Poeta se faz vidente através de um longo, imenso e racional desregramento de todos os sentidos" (RIMBAUD, 1985, p. 47, grifo do autor). Friedrich explica essa afirmação através de conceitos postulados por Baudelaire:

\footnotetext{
O objetivo do poetar é "chegar ao desconhecido", ou então, dito de outro modo: "escrutar o invisível, ouvir o inaudível". Já conhecemos estes conceitos: derivam de Baudelaire e são, aqui e lá, palavras-chave para indicar a transcendência vazia. Tampouco Rimbaud lhes dá uma definição mais precisa. Permanece na caracterização negativa do objetivo perseguido; distingue-se como o não-usual, não-real, como o outro pura e simplesmente, mas não lhe dá conteúdo (FRIEDRICH, 1978, p. 62, grifo do autor).
}

O desregramento dos sentidos, o ouvir o inaudível, manifestam-se no poema quando, ao referir-se à vidência, o eu lírico está submetido às palavras e à natureza representada pela árvore. Se no acaso o eu lírico encontra a palavra e declara a árvore, na vidência a palavra é quem requisita seu corpo para ser proferida, e a árvore é quem diz. Gomes, de forma um pouco diferente, também explica o conceito de Rimbaud por meio de postulados de Baudelaire; segundo ele, a afirmação baudelairiana que diz "o poeta deve ser um decifrador de símbolos" (GOMES, 1985, p. 16) equipara-se à noção de vidência de Rimbaud. Nesse sentido, o vidente do poeta francês está próximo ao vidente definido pelo dicionário; porém, se por um lado este decifra presente, passado e futuro, aquele decifra símbolos. Esse deciframento de símbolos, permitido pela capacidade vidente do poeta, surge no poema de Carpi quando o eu lírico torna-se instrumento, na vidência, para que a palavra seja proferida, em oposição ao acaso, à casualidade, em que é o eu lírico quem simplesmente encontra a palavra. Também é na vidência que a árvore diz ao eu lírico: “[...] Não vinga / jogares um grão de minha espécie / no coração de um sulco. Terás / de ser-me a terra do grão em ti / enterrado. Sem a visão do fruto" (CARPI, 1992, p. 67). O eu lírico, que apenas ouve sem responder, novamente, está submetido à natureza. A árvore é quem lhe requisita como 
terra à própria semente (grão), a qual deve ser aceita pelo eu lírico, ainda que esse desconheça o resultado, o futuro, aquilo que será revelado, "a visão do fruto" conforme consta no último verso. Assim, o poeta vidente aqui se apresenta no eu lírico que, na vidência, em oposição ao acaso, tem a revelação, a decifração, através da palavra que toma seu corpo para ser proferida e da árvore que desse corpo faz terra para frutificar seu grão.

Apesar da evocação do corpo, no poema manifesta-se o que Friedrich chama de "despersonalização da lírica moderna" (FRIEDRICH, 1978, p. 36), iniciada com Baudelaire. Usando como exemplo As flores do mal, o autor explica que, nessa obra, nenhum dos poemas pode ser explicado utilizando os dados biográficos do poeta. Assim, a lírica não mais é considerada como fruto da unidade entre a poesia e a pessoa empírica do artista, como anteriormente pretenderam os românticos. O "eu" voltado sobre si mesmo presente em As flores do mal - e em grande parte da lírica moderna apesar de autocentrado, pouco ou nada olha para o eu empírico. Sobre isso, Friedrich ainda afirma que

\begin{abstract}
Junto com Rimbaud, Mallarmé introduz o mais radical abandono da lírica baseada na vivência e na confissão, portanto, de um tipo de poesia que ainda estava, naquela época, personificada, com grandeza, por Verlaine. É verdade que também a lírica anterior, desde os trovadores até a época anterior ao Romantismo, só em alguns casos recorre a vivências, só raras vezes é comunicação, em forma de diário, de sentimentos pessoais; o equívoco de alguns historiadores da literatura, contagiados pelo Romantismo, fez com que se considerasse a lírica, em seu conjunto, desse modo. [...] A lírica moderna exclui não só a pessoa particular, mas também a humanidade normal. Nenhuma das poesias de Mallarmé [dentre aquelas analisadas na obra de Friedrich] poderia ser interpretada biograficamente, mesmo se por razões de curiosidade e comodidade este tipo de análise tenha sido tentado repetidas vezes. Mas tampouco há alguma poesia que se possa interpretar como linguagem de uma alegria que todos nós conhecemos, de um pesar que cada um compreende, porque o tem dentro de si. Mallarmé compõe suas poesias a partir de um centro para o qual é dificílimo encontrar um nome (FRIEDRICH, 1978, p. 110).
\end{abstract}

O mesmo se dá no já mencionado poema de Carpi, assim como nos demais a serem analisados neste trabalho: não é possível, mesmo que apenas por mera curiosidade, buscar qualquer traço biográfico da poetisa ou seu eu empírico nos textos. A poesia "despersonalizada", à época de Mallarmé, serviu também como ruptura da visão romântica, que considerava a lírica apenas como expressão das vivências do poeta; a poesia, a partir daí, passou a ser tratada como fruto do trabalho intelectual do artista (FRIEDRICH, 1978). Relacionado a isso está o fato de que os poemas passaram a constituir-se em uma linguagem que aponta para uma emoção a qual é difícil nomear, conforme explica Friedrich sobre Mallarmé - em Carpi isso também ocorre, ainda que de maneira bem menos radical. Na obra da poetisa, observa-se uma longa depuração do processo de profunda ruptura que se deu com os simbolistas franceses, assim resumida por Friedrich:

Interioridade neutra em vez de sentimento, fantasia em vez de realidade, fragmentos do mundo em vez de unidade do mundo, mistura daquilo que é heterogêneo, caos, fascinação por meio da obscuridade e da magia linguística, mas também um operar frio análogo ao resultado pela matemática, que alheia o habitual: esta é exatamente a estrutura dentro da 
qual se situarão a teoria poética de Baudelaire, a lírica de Rimbaud, de Mallarmé e a dos poetas hodiernos (FRIEDRICH, 1978, p. 29).

A obscuridade e o hermetismo, muitas vezes levado ao extremo por esses poetas, está presente nos poemas estudados nesta pesquisa, mas de uma maneira bastante suavizada em alguns casos, conforme será possível constatar. Porém, se, em Carpi, essa expressão hermética encontra-se abrandada, parte dos objetivos de tal expressão permanece de maneira consistente. A obscuridade, na obra dos franceses, buscava a preservação do campo da obra de arte, a compreensão do caótico mundo moderno e uma poesia de efeito sugestivo. Na poesia de Mallarmé, por exemplo, "o leitor não deve decifrar, mas sim chegar ele próprio ao enigmático, onde, intuindo decifrações, mas não as concluindo prematuramente, pode até mesmo pensar em possibilidades de interpretação da poesia que talvez nem sequer figuravam no plano do autor" (FRIEDRICH, 1978, p. 122). Também para Mallarmé e, segundo Friedrich, para quase toda produção lírica surgida depois desse poeta, "é significativo que seja mantida a única ponte com o leitor no efeito sugestivo da poesia" (FRIEDRICH, 1978, p. 122). O sentido atribuído ao poema de Carpi só é possível pelo hermetismo e pela sugestão que coabitam o texto. Não é possível saber - e tampouco é esse aqui o objetivo - se a relação entre a vidência do poema e o poeta vidente de Rimbaud foi algo pensado pela poetisa. Contudo, essa interpretação torna-se possível uma vez que o poema tem um forte caráter sugestivo, permitindo leituras e decifrações inúmeras e diversas. Essa característica também se faz presente no próximo poema a ser analisado, de número 64 de Vidência e acaso:

\author{
Renuncio à fortuna paterna \\ Dos acasos e deserdada, sem \\ meios, estanco o pus de toda \\ a ferida e beijo na decomposição, \\ o fogo sem chama, a voz sem febre, \\ da vidência desfalecida de amor (CARPI, 1992, p. 74).
}

O poema, formado por um período único, apresenta - conforme o modelo de Mallarmé - "um acontecimento simbólico com muitas possibilidades de interpretação" (FRIEDRICH, 1978, p. 133), neste caso, a renúncia à fortuna paterna. E essa pode ser interpretada como a forma de viver um amor não aprovado pela família, pois deserdada e sem meios - após renunciar à fortuna paterna - é quando a ferida é estancada - é curada - e o fogo sem chamas - o próprio amor - é beijado. Porém, também é possível uma leitura em que a renúncia à fortuna paterna seja interpretada como repúdio ao passado. Segundo Friedrich, na poesia de Rimbaud quando o passado torna-se um peso - "devido ao extinguir-se da genuína consciência de continuidade e à sua substituição pelo historicismo e pelas coleções em museus" (FRIEDRICH, 1978, p. 65) - é produzido, durante o século XIX, "uma reação que conduz à repulsa de tudo aquilo que é passado. Esta permanecerá uma característica permanente da arte e da poesia modernas" (FRIEDRICH, 1978, p. 65). Ao utilizar como exemplo o poema Vénus nadyomène, de Rimbaud, em que é parodiado um dos mais belos mitos figurativos - $\mathrm{o}$ nascimento de Afrodite - Friedrich explica: 
beleza; é um ataque movido pelo desafogo de uma tendência à deformação, que - e aqui está o mais curioso - possui, por outro lado, suficiente qualidade artística para imprimir nas fealdades o vigor de uma lógica estilística (FRIEDRICH, 1978, p. 65).

O mito de Vênus, no poema, é colocado de maneira grotesca a ponto de não causar o riso da paródia típica, constituindo assim um "desabafo contra a beleza e a tradição na poesia" (FRIEDRICH, 1978, p. 65). No poema de Carpi, a recusa ao passado surge não só na renúncia à herança paterna, mas também na presença dos elementos grotescos e do feio - o pus, a ferida, a decomposição - que, segundo Friedrich, atentariam contra a beleza e a tradição - elementos, esses, costumeiros da poesia que antecede a lírica moderna. O romântico Victor Hugo foi quem primeiramente incluiu em sua teoria do grotesco o elemento do "feio". Com isso, o que até então era "desqualificado, permitido só nos gêneros literários inferiores e nas zonas marginais da arte plástica, vem elevado a um valor expressivo metafísico" (FRIEDRICH, 1978, p. 33). Victor Hugo, assim, dá um novo papel ao feio: não mais se trata unicamente do "oposto ao belo, mas de um valor em si" (FRIEDRICH, 1978, p. 33). A partir do teorizado por Victor Hugo, Friedrich explica a relação do grotesco com a "alma moderna" que emerge dos três poetas centrais de sua análise:

\begin{abstract}
O grotesco deve aliviar-nos da beleza e, com sua "voz estridente", afastar sua monotonia. Reflete a dissonância entre os estratos animais e os estratos superiores do homem. Reduzindo os fenômenos a fragmentos, manifesta que o "grande todo" nos é perceptível apenas como fragmento, visto que o "todo" não concorda com o homem. O que é todo? É significativo que a resposta falte ou seja confusa. É uma transcendência vazia, mesmo se puder ser concebida de maneira cristã, como acredita Victor Hugo. Para ele só existem seus fragmentos nas caricaturas do grotesco e, mesmo estas, já nada têm a ver com o riso. O riso do grotesco, assim interpretado, cede lugar ao sorriso irônico ou à horripilação. Torna-se trejeito, excitação provocante e estímulo de uma inquietude à qual a alma moderna aspira mais que à distensão (FRIEDRICH, 1978, p. 33).
\end{abstract}

Levando essa questão ao poeta Baudelaire, Friedrich afirma que "mais veemente do que até então, a anormalidade anuncia-se como premissa do poetar moderno, e também como uma de suas razões de ser: irritação contra o banal e o tradicional que, aos olhos de Baudelaire, está contido também na beleza do estilo antigo" (FRIEDRICH, 1978, p. 44). Em última instância, é também essa fuga do que é banal e o choque que se dá pela presença do feio o que busca Rimbaud quando insere o elemento grotesco em seus poemas. Segundo Friedrich,

Com Rimbaud, ele [o feio] recebe, então, a tarefa de servir a uma energia sensitiva que impele à mais violenta deformação do real sensível. Uma poesia que toma por meta nos seus objetivos menos os conteúdos que as relações de tensão sobre-objetiva necessita também do feio porque este, como provocação ao sentimento natural da beleza, produz aquela dramaticidade chocante que se deve entabelecer entre texto e leitor (FRIEDRICH, 1978, p. 77).

No poema de Carpi, tal choque é potencializado pela proximidade entre as palavras pus, ferida, decomposição e beijo e amor. Da presença de ideias antitéticas emerge a dissonância ou, em outras palavras, a tensão causadora de inquietude. Essa 
tensão surge no poema mais uma vez por meio do conflito entre vidência e acaso, já identificado no poema anterior. Isso porque o eu lírico renuncia à fortuna paterna, recebida pelo acaso, para beijar uma vidência tomada de amor; assim, esta é escolhida em detrimento ao acaso. A herança paterna, legado da casualidade, é preterida em favor da vidência - onde reside a adoração, o fascínio, o fogo que não queima. Ao tratar da dissonância em Baudelaire, Friedrich aponta que uma exacerbação de antíteses está presente em quase toda a lírica e que,

\begin{abstract}
Muitas vezes, comprime-se no espaço mais conciso e torna-se dissonância lexical, como "grandeza suja", "caído e encantador", "horror sedutor", "negro e luminoso". Esta aproximação do que normalmente é incompatível chama-se oxymoron. É uma antiga figura do discurso poético, apropriada para exprimir estados complexos de alma. Em Baudelaire, sobressai por seu emprego desmedido. É a figura chave de sua dissonância fundamental (FRIEDRICH, 1978, p. 46).
\end{abstract}

Ainda que no poema de Carpi os vocábulos não estejam necessariamente lado a lado - a exemplo de "horror sedutor", mencionado por Friedrich - é evidente o contraste entre, por exemplo, pus e amor, ferida e beijo. O amor, um tema clássico da poesia, do belo, é colocado no poema lado a lado do grotesco, causando por isso o estranhamento, a dramaticidade que traz a tensão entre texto e leitor, mencionada por Friedrich. Ao abordar essa questão na poesia de Rimbaud, o autor assinala a incoerência existente entre imagens tão diversas. E, além disso, "como agravante, acresce o fato de que os complexos de imagens isoladas nascem da mistura das coisas mais opostas, da combinação daquilo que, objetivamente, é inconciliável, do belo com o repugnante, do sórdido com o extático" (FRIEDRICH, 1978, p. 74). Nesse sentido, o poema de Carpi se constitui como exemplar dessa combinação de opostos presente em Rimbaud, mas não só: em toda a lírica moderna.

Também é evidente no primeiro verso da última estrofe a imagem paradoxal do fogo sem chama - o que nos remete ao "Amor é um fogo que arde sem se ver" (CAMÕES, 2016, p. 16), soneto pleno de paradoxos em que o eu lírico dá a sua definição do amor. A definição desse sentimento como algo paradoxal também surge em A força de não ter força, de Carpi. No livro, os 89 poemas - não nomeados, assim como em Vidência e acaso - são dividos em três capítulos ("Livro I: Do amado e do não amado"; "Livro II: A vertigem sem abismo"; "Elegias à vastidão de um epílogo"). Nessa obra, o elo temático entre os poemas é o amor, "que ultrapassa limites convencionais de tempo e de espaço, disseminando a junção de contrários [...]. Dessa forma, o conteúdo imagístico textual é resultado de um contraste de antíteses semânticas que se coadunam de maneira relevante em toda a escritura" (ZIEGLER, 2015, p. 57). Esse contraste semântico surge no primeiro poema de $A$ força de não ter força que, assim como acontece em As flores do mal, antecipa todo o sentido da obra:

\footnotetext{
Amor, essa força de não ter força; essa paz não

dando a paz; esse rosto incandescente, nunca

lido, que se sobrepõe aos demais e reluta
} 
quando todos fenecem

e mais se aviva, encoberto (CARPI, 2003, p. 11).

Segundo Friedrich (1978), o fato de, no livro de Baudelaire, a ordem dos poemas ser parte da construção arquitetônica da obra é uma característica que afasta o poeta francês dos seus antecessores românticos. Isso porque, nas obras líricas românticas, a disposição dos poemas se dava conforme a casualidade da inspiração. Assim, essa organização não constituía uma esfera de significação, diferentemente do que acontece em As flores do mal e também, é possível afirmar, em A força de não ter força constatação que é ratificada, também, pela divisão dos poemas em capítulos. Além da oposição de ideias - "a força de não ter força"; "a paz não dando paz"; "fenecer" e "avivar" - o poema traz a metáfora do "rosto incandescente nunca lido". Friedrich afirma que, por meio da metáfora, a poesia "realiza uma transposição daquilo que é objetivo em imagens que não existem no mundo real" (FRIEDRICH, 1978, p. 87), o que se dá no poema de Carpi. A combinação das palavras "rosto", "incandescente", "nunca" e "lido", cria uma imagem nova para definir o amor: uma face inflamada, iluminada e quente, conhecida, mas nunca compreendida. Com isso, ainda, mais uma ideia contraditória se apresenta: o eu lírico, ao definir o amor, confirma que este nunca foi decifrado, lido.

Friedrich, quando aborda o estilo tardio de Mallarmé, afirma que o poeta deseja "que as palavras não falem mediante relações gramaticais, mas irradiem de si próprias suas muitas possibilidades de sentido" (FRIEDRICH, 1978, p. 102). O poema de Carpi, ainda que bem menos hermético do que os dois anteriormente analisados, oferece diferentes sentidos e significações possíveis. Quando são postos em ligação "rosto", "incandescente" e "lido", vocábulos normalmente não relacionados, emergem - através da leitura completa do poema - os sentidos de "rosto" como algo que se vê, que se conhece; "incandescente" como iluminado, mas também como algo que pode queimar; e "lido" como compreendido e/ou apreendido. O eu lírico, assim, define o amor como contraditório, bom e mau ao mesmo tempo e, por meio dos versos finais "[...] que se sobrepõe / aos demais e reluta / quando todos fenecem / e mais se aviva, encoberto" (CARPI, 2003, p. 11), como aquilo, acima de tudo o mais, que permanece, que verdadeiramente importa. Essa definição torna-se uma leitura possível pelas metáforas, paradoxos e antíteses presentes no poema.

Ainda que imagens contraditórias não sejam privilégio da lírica moderna, para Friedrich, conforme já foi apontado, a exacerbação de ideias antitéticas surge, nessa lírica - a exemplo de Baudelaire - como chave da dissonância fundamental que impregna a poesia. Essa dissonância se apresenta, ainda que não da mesma maneira, no próprio conceito de modernidade de Baudelaire, que segundo Friedrich, sendo dissonante, "[...] faz do negativo, ao mesmo tempo, algo fascinador. O mísero, o decadente, o mau, o noturno, o artificial, oferecem matérias estimulantes que querem ser apreendidas poeticamente. Contêm mistérios que guiam a poesia a novos caminhos" (FRIEDRICH, 1978, p. 43). Dentre esses novos caminhos, "o estilo simbólico moderno que transforma tudo em sinais para expressar outra coisa, sem assegurar essa outra coisa numa tessitura de sentido coerente, deve necessariamente trabalhar com símbolos autárquicos que permanecem subtraídos a uma compreensão limitante" (FRIEDRICH, 1978, p. 120). O segundo poema analisado de A força de não ter força traz deliberadamente a questão do símbolo: 


\author{
como laranjas que se juntaram \\ uma a uma rente às cercas. \\ Nem tudo será transcrito. Algo \\ tem de ficar intocado. O mosto \\ do que provas. A palavra contém \\ o que sobe. O símbolo aprisiona \\ o rastro. $\mathrm{O}$ que afunda não pode \\ ser consumido. Nem raspado (CARPI, 2003, p. 36).
}

Neste texto, um dos poucos no livro que não traz expressa a questão do amor, é possível identificar a influência do estilo simbólico moderno, mencionado por Friedrich. Tal estilo, no entanto, encontra-se bastante atenuado pelo longo processo de depuração proporcionado pelo distanciamento temporal entre os simbolistas franceses e Maria Carpi. No poema de Carpi, apesar da forte carga simbólica, é possível depreender uma construção de sentido coerente. O eu lírico, valendo-se da linguagem metapoética, aborda o próprio ato do poetar. $\mathrm{O}$ eu lírico, ainda, vincula à criação poética, e à poesia em si, a capacidade sugestiva de uma lírica que diz sem dizer, de uma lírica que permite ao leitor intuir interpretações, mas nunca tê-las como certeza. Já no primeiro verso, é afirmado o gosto de permanecer nas entrelinhas ou, em outras palavras, no que pode apenas ser inferido. Essa afirmação, de forma diferente, volta a surgir no primeiro e no segundo verso da segunda estrofe: "Nem tudo será transcrito. Algo / tem de ficar intocado [...]" (CARPI, 2003, p. 36). Ou seja, nem tudo será colocado ostensivamente no poema - "transcrito" -, algo deve permanecer inacessível, distante - "intocado".

Na sequência, o eu lírico aproxima o fazer poético ao processo de fabricação do vinho: No "mosto" - suco das uvas que ainda não passou pelo processo de fermentação alcoólica - que é provado, a palavra contém o que "sobe" - no processo de fermentação, o que sobe, o que fica na superfície, são as cascas das uvas, principais responsáveis pela cor e sabor nos vinhos tintos (SAIBA..., 2016). A palavra, assim posta no poema, é reafirmada como central em sua significação, pois é ela a responsável pela "cor" e pelo "sabor". Por outro lado, os símbolos por ela contruídos são quem prendem, "aprisionam", o vestígio, o "rastro" de sentido sugerido pelo texto poético. O símbolo então é exaltado como responsável pelo efeito sugestivo do poema. Nos penúltimo e último versos é retomada a metáfora enológica: "[...] $\mathrm{O}$ que afunda não pode / ser consumido" (CARPI, 2003, p. 36). Esses versos reproduzem o final do processo de fermentação do vinho, quando leveduras, bactérias e matéria orgânica ficam depositados no fundo do tanque utilizado. Tais resíduos são separados e dispensados, podendo servir apenas de adubo (SAIBA..., 2016). Assim, o que está no fundo ou em profundidade na construção de sentido de um poema nunca será "consumido", alcançado e, assim, esgotado pelo leitor. Porém, se a significação das entrelinhas não pode ser completamente atingida, ao mesmo tempo ela não pode ser eliminada, "raspada", pois se fazem presentes os vestígios deixados pelos símbolos, ainda que obscuramente relevados. Friedrich, quando analisa Mallarmé, aborda a presença do ato da criação poética na obra do francês:

Mallarmé [...] fundamenta ontologicamente a obscuridade do poetar assim como seu afastamento de uma compreensibilidade limitante; pois a união entre ideia artística e reflexão sobre a arte é agora exaltada nele por um pensamento que gira em torno do Ser absoluto (equiparado ao Nada) e em torno da revelação desde para com a linguagem. Teórica - e sempre 
prudentemente -, este pensamento se manifesta nos ensaios de Divagations e em algumas cartas. Mas encontra sua configuração verdadeira na poesia (FRIEDRICH, 1978, p. 96).

O poema de Carpi releva-se próximo a Mallarmé primeiro ao abordar o fazer poético e, segundo, ao colocar como obrigação o ato de deixar no poema algo não exposto, expressada pelo emprego da locução verbal "tem de ficar" (CARPI, 2003, p. 36), no segundo verso da segunda estrofe. O que primeiramente era apenas uma preferência, "Gosto de ficar nas entrelinhas" (CARPI, 2003, p. 36), torna-se imperativo à criação lírica conforme se dá o andamento do texto. Ainda, ao empregar a metáfora da fabricação do vinho para explicar a feitura do poema, o eu lírico eleva a poesia a um patamar quase divino. Isso porque, segundo o Dicionário de símbolos de Chevalier e Gheerbrant (1991), o vinho simboliza o elixir da vida e da imortalidade. Sendo assim, constitui-se aqui o que Friedrich chama de "metáfora absoluta", aquela que serve não só à comparação, mas cria uma identidade. Em Rimbaud, ela correspondeu a um traço fundamental de sua poesia, e na lírica posterior permaneceu como um meio estilístico dominante (FRIEDRICH, 1978). Se, nos primeiros versos a metáfora das "[...] laranjas que se juntaram / uma a uma rente às cercas" (CARPI, 2003, p. 36) serve como mera comparação e construção de imagem, ao comparar a poesia com o vinho, o eu lírico revela uma visão de mundo e, assim, parte da sua identidade. Identidade essa que considera a poesia como um caminho para a vida eterna.

Além dos aspectos até aqui apresentados, outras características surgidas ou acentuadas pelos primeiros representantes da lírica moderna ficam evidentes ao se ler Maria Carpi. Um desses aspectos é o uso do verso sem rima e do verso livre - ainda que a poetisa siga uma certa regularidade métrica. Friedrich aponta que a poesia Marine, de 1872, de autoria de Rimbaud,

\footnotetext{
é, na França, o primeiro exemplo de verso completamente livre: dez versos de metro distinto; sem rima, sem sucessão regular de rimas masculinas e femininas. O abandono da métrica rigorosa foi, na França (e o é ainda hoje), mais notado que em outros países e também um sintoma (mais fortemente sentido) da anormalidade na composição poética. [...] A partir de "Marine", o verso livre domina cada vez mais na lírica francesa moderna. [...] O verso livre torna-se o indício formal próprio daquele tipo lírico que - consciente ou inconscientemente - segue o exemplo de Rimbaud (FRIEDRICH, 1978, p. 84).
}

Considerando as colocações de Friedrich, pode-se afirmar que Carpi, ao abrir mão da rima e de uma métrica rigorasa, confirma-se como seguidora da lírica de Rimbaud. A fragmentação, outra característica na lírica moderna, também se faz presente; o todo fragmentado, o mundo estilhaçado e não mais compreensível, manifesta-se nos quatro poemas através da separação dos períodos não só em diferentes versos, mas em diferentes estrofes. Outro aspecto oriundo da poesia moderna é a utilização da sonoridade da língua como elemento de significação do poema. Friedrich explica que a possibilidade de surgir temas e motivos do texto lírico por meio do plano fônico é anterior aos simbolistas franceses. Isso se dava pelas "possibilidades de combinações das sonoridades da língua e das oscilações associativas dos significados das palavras" (FRIEDRICH, 1978, p. 91). No entanto, o autor afirma que é Rimbaud quem inova na utilização desse procedimento, ao empregá-lo com uma ousadia sem precedentes. Isso porque a poesia rimbaudiana desconsiderou a compreensibilidade 
comum e serviu-se dessa prática de maneira que a palavra, como sonoridade e sugestão, tem maior importância do que a palavra que se presta a uma tessitura lógica de sentido (FRIEDRICH, 1978). Ainda que em Carpi a sonoridade não esteja acima da lógica, é possível identificar em todos os quatro poemas a relação entre o plano sonoro e o plano semântico. No primeiro poema, a recorrência dos fonemas $/ \mathrm{r} / \mathrm{e} / \mathrm{rr} / \mathrm{reforça} \mathrm{o} \mathrm{caráter}$ telúrico das imagens. Já no segundo texto, o confronto com o passado e as ideias antitéticas ganham força com a oposição entre fonemas surdos e sonoros $/ \mathrm{p} / \mathrm{e} / \mathrm{b} / \mathrm{t} / \mathrm{t} / \mathrm{e}$ /d/, /f/ e /v/, /s/ e /z/, difusos - alguns mais, outros menos - por todos os versos. No terceiro poema, a presença dos fonemas fricativos /f/ e /s/, nas duas primeiras estrofes, remete ao fenecimento citado na última. Ao mesmo tempo, a força sonora dos fonemas oclusivos /k/, /b/, /p/, /d/ e /t/ opõe-se ao fenecimento - representando assim o amor, aquilo que "mais se aviva" (CARPI, 2003, p. 11), mencionado no último verso. Por fim, no último poema, a presença contínua do som sibilante do fonema fricativo /s/ confirma um texto que pretende permanecer apenas no susurro das entrelinhas.

Tendo como exemplo Maria Carpi, é possível afirmar que a influência dos primeiros representantes da lírica moderna segue na atual poesia brasileira. A escritora, nos poemas analisados, mostra uma fase da lírica em que os conceitos mais radicais, que serviram de ruptura à época de Baudelaire, Rimbaud e Mallarmé, hoje encontram-se assimilados e, logo, amenizados. Ainda assim, permanecem o poeta como vidente, a despersonalização, a emoções não nomeadas, a ampliação dos planos responsáveis pelo sentido do poema - desde o sonoro até o da forma como se organizam dentro de um livro -, a renúncia ao passado, a presença do "feio", o caráter simbólico, a tensão dissonante, a acentuação da presença de ideias antitéticas e contraditórias que buscam explicar o caos do mundo moderno, o hermetismo e, consequentemente, o efeito sugestivo - razão pela qual muitas vezes não há uma lógica externa a partir da qual o poema possa ser pensado. Se a genuinidade do Simbolismo no Brasil é questionada por diversos estudiosos, a influência dos simbolistas franceses é presença inegável na lírica brasileira, atravessando todo o século XX e avançando neste começo de século XXI. Evidente, também, é a atualidade da obra de Friedrich. Apesar dos seus mais de 60 anos, as afirmações do autor permanecem válidas e seguem confirmando a atualidade, também, do "moderno" consolidado pelos poetas franceses.

\section{REFERÊNCIAS}

BOSI, Alfredo. História concisa da literatura brasileira. 3. ed. São Paulo: Cultrix, 1982.

BERARDINELLI, Alfonso. Da poesia à prosa. Tradução: Maurício Santana Dias. São Paulo: Cosac Naify, 2007.

CAMÕES, Luís de. Sonetos. São Paulo: Via Leitura, 2016.

CARPI, Maria. A força de não ter força. São Paulo: Escrituras, 2003.

CARPI, Maria. Vidência e acaso. Porto Alegre: Movimento, 1992.

CHEVALIER, Jean; GHEERBRANT, Alain. Dicionário de símbolos: Mitos, sonhos, 
costumes, gestos, formas, figuras, cores, números. Tradução: Vera da Costa Silva et al. 3. ed. Rio de Janeiro: José Olympio, 1991.

COELHO, Nelly Novaes. A poesia de Maria Carpi: uma viagem iniciática em busca do Ser. In: RIO GRANDE DO SUL. Secretaria de Estado da Cultura. Instituto Estadual do Livro. Maria Carpi. Porto Alegre: IEL: CORAG, 2002. (Autores Gaúchos - Nova Série; v. 9)

COUTINHO, Afrânio. Introdução à literatura no Brasil. 10 ed. Rio de Janeiro: Civilização Brasileira, 1980.

FRIEDRICH, Hugo. Estrutura da lírica moderna: da metade do século XIX a medos do séculos XX. Tradução: Marise M. Curioni. São Paulo: Duas Cidades, 1978.

GOMES, Álvaro Cardoso. Introdução. In: GOMES, Álvaro Cardoso. A estética simbolista. São Paulo: Cultrix, 1985. p. 9-29.

HOUAISS, Antonio. Pequeno dicionário Houaiss da língua portuguesa. São Paulo: Moderna, 2015.

MORICONI, Italo. Como e por que ler a poesia brasileira do século XX. Rio de Janeiro: Objetiva, 2002.

SAIBA como o vinho é produzido. Revista Adega, São Paulo, jan. 2016. Disponível em: http://revistaadega.uol.com.br/artigo/saiba-como-o-vinho-e-produzido_10511.html. Acesso em: 21 jun. 2018.

RIMBAUD, Arthur. O poeta vidente. In: GOMES, Álvaro Cardoso. A estética simbolista. São Paulo: Cultrix, 1985. p. 47-51.

ZIEGLER, Adriane Marconatto. Poética dos quatro elementos na obra de Maria Carpi. Dissertação (Mestrado em Letras/ Leitura e Cognição) - Departamento de Letras, Universidade de Santa Cruz do Sul, Rio Grande do Sul, Santa Cruz do Sul, 2015. 